\title{
Surface runoff and accelerated erosion in a peri-urban wellhead area in southeastern Brazil
}

\author{
Carlos Wilmer Costa ${ }^{1}$ (1) $\cdot$ Reinaldo Lorandi $^{1}$. José Augusto de Lollo ${ }^{2} \cdot$ Maryam Imani $^{3} \cdot$ Francisco Antônio Dupas ${ }^{4}$
}

Received: 8 September 2017 / Accepted: 18 February 2018 / Published online: 23 February 2018

(c) Springer-Verlag GmbH Germany, part of Springer Nature 2018

\begin{abstract}
Degradation of hydrological conditions can adversely impact water resource quality and quantity. This degradation can generate social and economic losses, including losses for users outside the basin area. Therefore, studies focusing on surface runoff and accelerated erosion processes are needed to enable interventions that address degradation-induced challenges. In the present study, the surface runoff and accelerated erosion potential of the Feijão River basin were presented in charts at a 1:50,000 scale. The Feijão River basin has an area of $243.16 \mathrm{~km}^{2}$ and is used as the main water source for the city of São Carlos, Brazil. Geoenvironmental attributes, such as substrate, climate, relief, soil, water bodies and land cover and use, were integrated and assessed in a GIS environment, using a multicriteria analysis and weighted sum tool. The results show that a large part of the area (86.12\% of the basin) exhibits a low surface runoff potential and a moderate accelerated erosion potential. Accelerated erosive processes are triggered by changes in soil cover and have a direct relationship with the removal of existing vegetation and implementation of anthropogenic activities. In this case, as well as for most of the areas in southeastern Brazil, extensive grazing followed by sugar cane cultivation was the main driving force of erosion, acting as trigger for accelerated erosive processes at the water source area.
\end{abstract}

Keywords Geoenvironmental · GIS · Quaternary · Geomorphology · Ecosystem Services

Carlos Wilmer Costa

carloswilmercosta@gmail.com

Reinaldo Lorandi

lorandir@gmail.com

José Augusto de Lollo

ja_lollo@yahoo.com

Maryam Imani

maryam.imani@anglia.ac.uk

Francisco Antônio Dupas

dupas_unifei@hotmail.com

1 Environmental Sciences Department, Federal University of São Carlos, Campus São Carlos, Rodovia Washington Luís, km 235 - SP-310, São Carlos, SP CEP 13565-905, Brazil

2 Civil Engineering Department, Universidade Estadual Paulista "Júlio de Mesquita Filho", Campus Ilha Solteira, Avenida Brasil, 56, Centro, Ilha Solteira, SP CEP 15385-000, Brazil

3 Department of Engineering and the Built Environment, Anglia Ruskin University, Chelmsford Campus, Bishop Hall Lane, Chelmsford, Essex CM1 1SQ, UK

4 Institute of Natural Resources, Federal University of Itajubá, Av. BPS 1303, Pinheirinho, Itajubá, MG CEP 37500-000, Brazil

\section{Introduction}

There is no terrestrial ecosystem free of human influence. Approximately one-third to one-half of the surface of the globe has been transformed by anthropic actions (Vitousek et al. 1997). Notably, in both developed and developing countries, production of goods and services has centered on the exploitation of natural resources without considering their regenerative capabilities (Ravenga 2005). This development model has led to a decline in natural ecosystem conditions (Rapport and Maffi 2010).

Anthropogenic activities such as cattle grazing, urbanization and industrialization without proper planning and consideration of technical criteria are activities that most compromise ecosystem services (Millennium Ecosystem Assessment 2005; Eigenbrod et al. 2009), especially water supplies (Montes and Ruiz 2008; WWAP 2015) in wellhead areas (Costa et al. 2015; Machado et al. 2016).

In terms of soil resources, surface runoff and accelerated erosion processes are probably the main agents of degradation that result in the greatest economic, social and 
environmental losses (Bayon et al. 2012; Vente et al. 2013; Vrieling et al. 2014; Reusser et al. 2015).

Globally, it is estimated that $70 \%$ of soils are degraded by physical, chemical and biological factors (FAO 2011). In the USA, soil erosion represents an estimated annual cost between US\$ 30 billion (Uri and Lewis 1998) and US\$ 44 billion (Pimentel et al. 1995). In the UK, this cost is estimated to be $£ 90$ million (GREAT BRITAIN_Environment Agency 2002).

Globally, hydric erosion compromises soils, and the greatest risk factors are found in tropical regions (Morgan 2005). In Brazil, where soil is intensively used for agricultural and livestock activities, it is estimated that approximately 500 million tons of soil are lost annually (Bertoni and Lombardi Neto 2012).

Triggering mechanisms for erosive processes are specific to each location, varying according to existing conditions that are minor compared to the set of natural conditions (Lollo and Sena 2013), such as precipitation; rocky substrates; chemical, physical and morphological properties of soil particles; the density of drainage; features favorable to artificial storage; vegetation cover; and soil use (Lal 1990; Valentin et al. 2005; Guerra et al. 2014; Zhou et al. 2016).

According to Bertoni and Lombardi Neto (2012), surface runoff is generally the most significant agent of transport when erosion is caused by rain, which is the main trigger for accelerated erosive processes.

In the headwaters of catchments areas, runoff induces soil erosion, carrying soil nutrients and agrochemicals, and accelerates the eutrophication of water bodies (Tundisi and Matsumura-Tundisi 2010; Galharte et al. 2014). Suspended soil particles increase turbidity and the cost of water treatment due to the need for filter installations. These sediments also cause siltation, reducing the flow capacity of the canal and the useful life of reservoirs (Uri and Lewis 1998).

Internationally, quantitative models for soil erosion are applied in an indirect manner and are normally utilized as a diagnostic tool for studying the natural environment and making land management decisions. Among these methods, it is worth highlighting parametric models such as USLE (Wischmeier and Smith 1978) and RUSLE (Renard et al. 1997), conceptual models such as SWAT (Neitsch et al. 2010) and models with a physical base such as PESERA (Kirkby et al. 2004) and EUROSEN (Morgan et al. 1998).

However, these models have significant limitations in assessing erosion consequences (Morgan 2005; Boardman 2006; Coulthard et al. 2012; Vente et al. 2013). Most of the models are limited to laminar erosion studies and do not represent efficient tools for areas that have a large potential for accelerated erosive processes to develop. In addition, most of the models do not take into account slope morphology variations but adopt rectilinear profiles as the standard condition. The authors of these studies have also highlighted that it is necessary to calibrate these models to tropical environments, given that most of the models were projected to simulate erosion that occurs in regions with temperate climates.

Considering this need for calibration, the present study assessed surface runoff and accelerated erosion processes in the Feijão River basin, the main surface water source for the city of São Carlos, SP, by extending the Pejon (1992) methodology proposal that seeks to contribute to territorial planning for the basin, which would undoubtedly have a positive impact on water resources upstream of the catchment.

Once natural basin conditions are similar to those of the large areas of the Paraná Basin, most of the information obtained in this study will be able to be used in other peri-urban wellhead areas with equivalent environmental conditions.

\section{Geoenvironmental characterization of the study area}

The Feijão River basin is located in the peri-urban zone of São Carlos (225,681 inhabitants) (SEADE 2016) in the central region of the state of São Paulo, approximately $230 \mathrm{~km}$ from the city of São Paulo. The basin accounts for approximately $27 \%$ of the water supply to the city of São Carlos (Costa et al. 2013). The area also provides subterranean sources of water from 72 wells distributed across the basin (BRASIL-CPRM 2016).

Residual soils and sediment units result from sandstone, basalt and diabase weathering, with differentiated geotechnical characteristics such as thickness, texture, mineral composition and permeability. Units were defined and mapped by Nishiyama (1991) (Fig. 1).

In South America, the basin is located in the sub-Andean Province, laid out on the geotectonic compartmentalization of Cráton Paraná, in the Paraná Province (Hasui 2012). The sedimentary basin of Paraná constitutes an upright synclinal complex of intracratonic fossa, with an accumulation of sedimentary and volcanic rocks (Milani et al. 1998). The geological characterization (Zuquette 1981; Nishiyama 1991; Perrota et al. 2005) and the geotechnical characteristics available for soil units (Nishiyama 1991) in the basin are shown in Table 1.

The drainage network has a sinuous character, and its extension is approximately $248 \mathrm{~km}$. The watercourses range from the first order to the fifth order (Strahler 1952), with $137 \mathrm{~km}$ of the watercourse being first order, $50.2 \mathrm{~km}$ being second order, $23.3 \mathrm{~km}$ being third order, $30.9 \mathrm{~km}$ being fourth order and $6.6 \mathrm{~km}$ being fifth order. The drainage pattern is dendritic (Christofoletti 1974).

According to the Köppen climatic classification, the area is midway between the classification Cwa and Aw, 

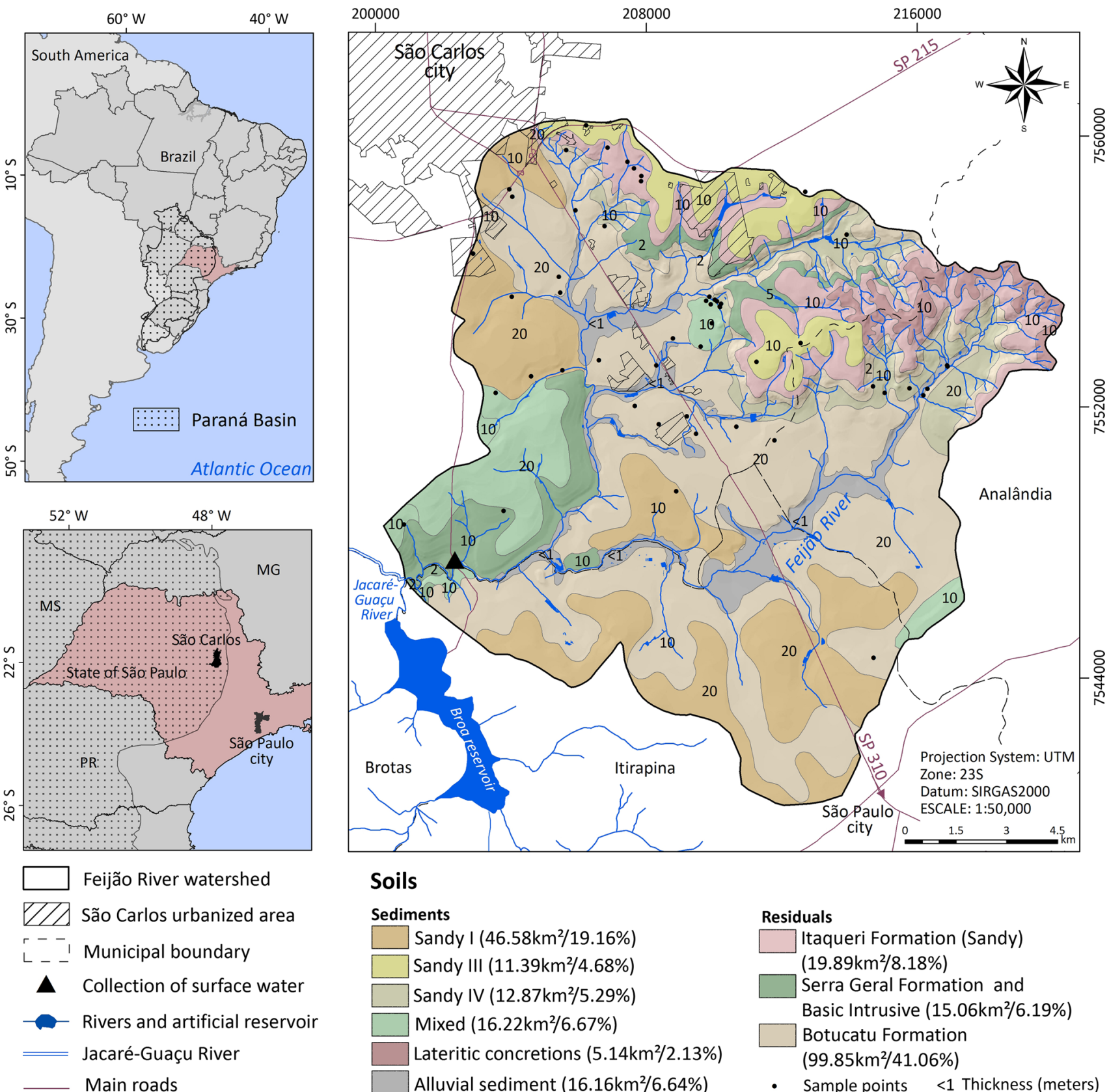

\section{Soils}

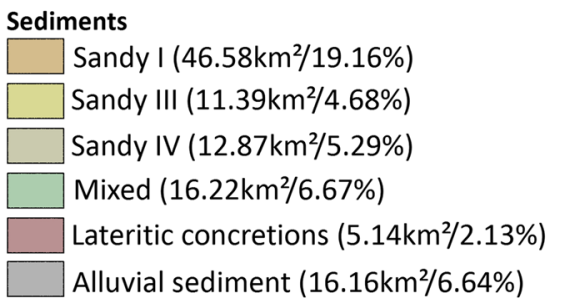

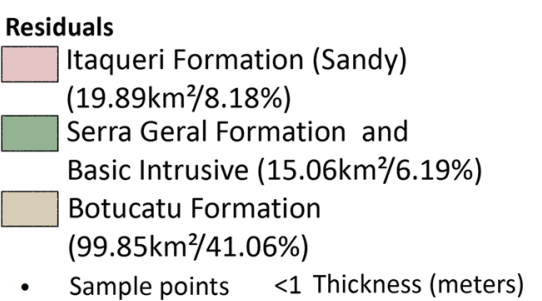

Fig. 1 Location and soil types in the Feijão River basin

characterized by a tropical climate with a humid summer and dry winter and an average temperature above $22{ }^{\circ} \mathrm{C}$ for the hottest month (Tolentino 2007). The climate of the region is also described as tropical without drought, with a strong influence from the two tropical and polar atmospheric oceanic systems, which explain the high rainfall levels and thermal variations (Mendonça and Danni-Oliveira 2007).

The current vegetation in the basin is highly diverse due to the climatic and soil conditions and human interference. The vegetation consists of Cerrado (sparsely vegetated savanna, small shrubs and wet field), as well as semi-deciduous forests, riparian areas and regeneration areas (Soares et al. 2003).

In the regional geomorphological context, the basin is located in the provincial basalt cuestas, where degradation reliefs predominate, in dissected plateaus. The area is made up of hilly reliefs (declivities of up to $15 \%$ and amplitudes of less than $100 \mathrm{~m}$ ) and mountainous reliefs (moderate to tall declivities, above 15\%, and local amplitudes of 100-300 m) (São Paulo, IPT 1981).

In the hilly relief areas, wide hills are the most prominent; there is a dominance of interfluvial areas with an 
Table 1 Lithostratigraphic units and soil types identified in the study area

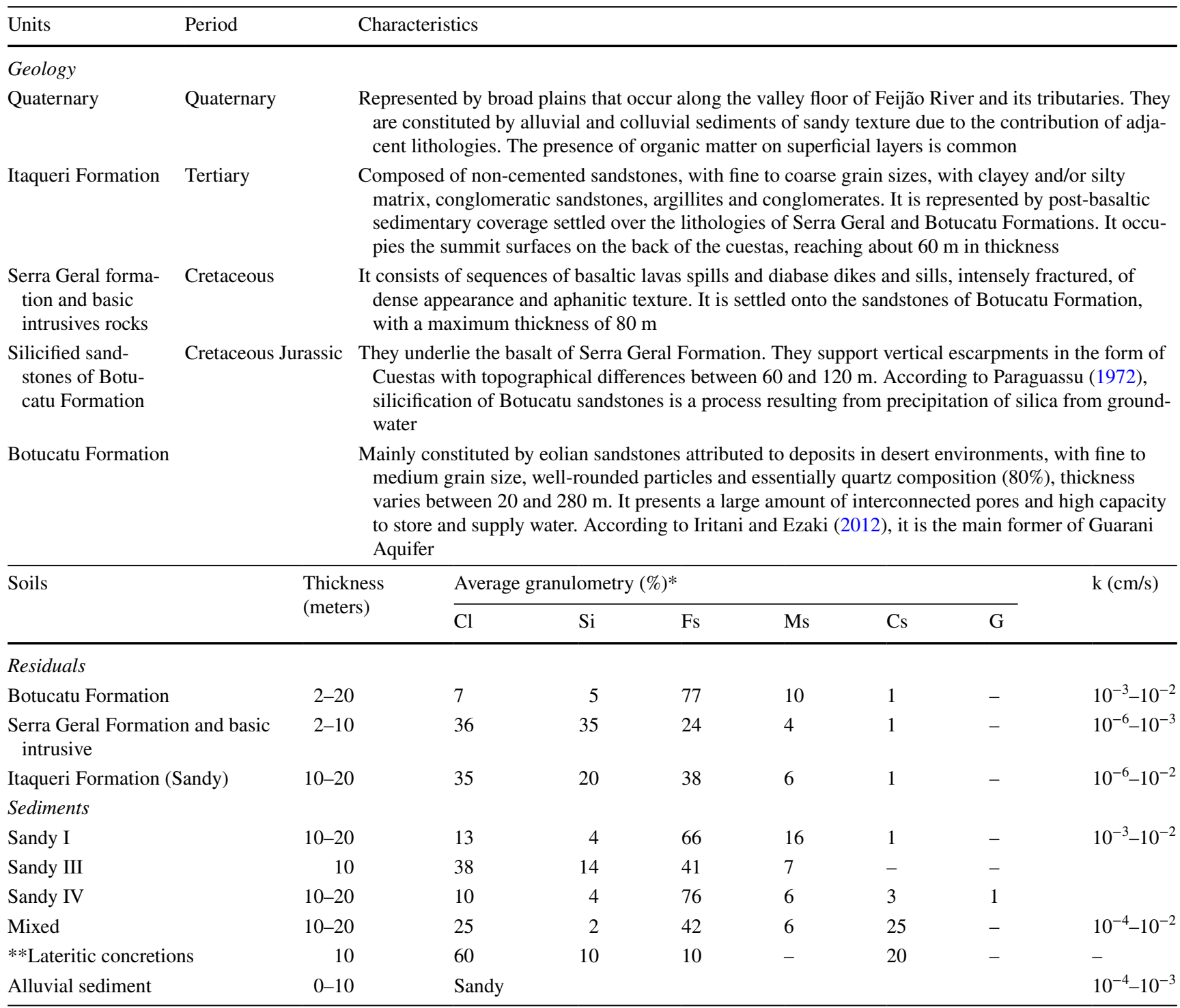

* Cl clay; Si silt; Fs fine sand; $M s$ medium sand; $C s$ coarse sand; $G$ gravel; $K$ permeability coefficients. Source: Nishiyama (1991)

** According to pedological units (Oliveira and Prado 1985)

area greater than $4 \mathrm{~km}^{2}$, extensive and flat peaks and slopes with rectilinear to convex profiles. There are also low-density drainage and open valleys with narrow interior alluvial plains. In the moderately hilly area, interfluvial areas predominate with areas of $1-4 \mathrm{~km}^{2}$, with flattened tops and slopes with convex to rectilinear profiles. These areas have low-intensity drainage with open to closed valleys with narrow interior alluvial plains.

In the mountainous relief areas, the subclass of rounded hills, which possess rounded tops that are locally flattened and gullied slopes with convex to rectilinear profiles, are dominant. There is local exposure of the rocks as well as the presence of short local spikes. Drainage is moderately dense, with a dendritic and sub-dendritic pattern and closed valleys.

\section{Materials and method}

To organize the digital data bank, primary and secondary data were utilized (Table 2).

The analytic process involving map algebra in a GIS environment required the preparation of information stored in geo-referenced, matrix structures with the same cell size $(10 \times 10 \mathrm{~m})$. Cartographic data treatment was carried out using ArcGIS ${ }^{\circledR}$ 10.2.2 software (ESRI 2013). The 
Table 2 Materials utilized

\begin{tabular}{|c|c|c|c|}
\hline Geoenvironmental attributes & Description & Source & Scale \\
\hline Geology & Geological maps & $\begin{array}{l}\text { Zuquette (1981), Nishiyama (1991), Geological Institute of } \\
\text { São Paulo State (1984) }\end{array}$ & $1: 50,000$ \\
\hline Soils & Cover materials & Nishiyama (1991) & $1: 50,000$ \\
\hline \multirow[t]{4}{*}{ Relief } & Steepness & Topography charts (IBGE 1971a, b): & $1: 50,000$ \\
\hline & & São Carlos - SF-23-Y-A-I-1 & $1: 50,000$ \\
\hline & & Corumbataí - SF-23-Y-A-I-2 & $1: 50,000$ \\
\hline & Slope shape & Topodata (INPE 2016) & \\
\hline Hydrography & Rivers and artificial reservoir & $\begin{array}{l}\text { Topography charts (IBGE 1971a, b) } \\
\text { GeoEye image of } 2011 \text { - Resolution } 0.5 \text { m (ESRI 2011) }\end{array}$ & \\
\hline Land cover and land use & Vegetation and land use & $\begin{array}{l}\text { GeoEye satellite images of } 2011 \\
\text { Resolution } 0.5 \mathrm{~m} \text { (ESRI 2011) }\end{array}$ & - \\
\hline Climate & Average annual rainfall 1986-2015 & $\begin{array}{l}\text { Hidro Web } \\
\text { (ANA 2016) }\end{array}$ & - \\
\hline
\end{tabular}

Universal Transverse Mercator (UTM) Projection and the Brazilian geodesic referencing system SIRGAS2000 (IBGE 2005) were used to georeference the information plans in the 23S Zone (Fig. 2).

Pejon's methodology (1992) was adopted to map the potential of surface runoff and accelerated erosion processes in the basins. This methodology effectively mirrors the characteristics, functions and dynamics of regional physical processes in southeastern Brazil because it includes a wide range of geosystem components and calibration for different natural conditions.

In this study, to methodologically advance the original proposal, hydrological parameters of precipitation, slope, shape and land cover and use were collected and analyzed to understand the surface runoff and accelerated erosion processes.

The approach consisted of several steps: (1) surface runoff chart construction, (2) erodibility index calculation, (3) inventory of geodynamic processes (rill and gully), (4) accelerated erosion potential chart production and (5) geodynamic processes representation on surface runoff and accelerated erosion charts (Fig. 3).

The methodology was developed based on a multicriteria analysis using map algebra in a GIS environment. According to McInnes et al. (2016), an analysis of multicriteria decisions provides a structured, auditable and transparent process that helps to inform and add rigor to multiple decisions.

Each geoenvironmental attribute, such as steepness, slope shape, geology, soils (genesis, texture, thickness, permeability and erodibility), rainfall, drainage density, features favorable to superficial storage and land use and cover, was mapped as a layer in raster format in the data bank. A weighting was attributed to each attribute, indicating the degree of influence of the attribute in the processes of surface runoff and accelerated erosion. The weights were determined based on the experience and knowledge of a team of interdisciplinary specialists.

Once the values were attributed to all the classes of the layers, the thematic maps were integrated using the weighted sum tool in GIS. Therefore, surface runoff and accelerated erosion potentials were classified as very low, low, medium, high and very high based on their occurrence.

Tables 3 and 4 synthesize weighting attribution.

Steepness has a direct influence on the speed of potential energy transformation to kinetic energy and therefore also on the speed of the water mass in movement leading to surface runoff (Florenzano 2008). Therefore, greater weighting was given to classes with more elevated steepness, given that the greater the steepness, the greater the speed and consequently, the greater the volume of sediment.

Surface runoff increases from concave to convex forms, passing through linearity, which presents greater stability (Guerra and Cunha 2003). In this case, a lower weighting was attributed to the convergent/concave segments of the slope, since they were inefficient at removing the sediment, mainly at the base of the slopes where depositing and infiltration of water are favored. On the other hand, the convex segments of the slope received the greatest weighting, since they show a greater divergence from the hydrological flow, contributing to surface runoff and denudation.

The contribution of geological units to surface runoff is related to the degree of cohesion of the rocks or, more specifically, the intensity of the connection between the minerals that constitute the rocks (Pejon 1992). In this case, a lower weighting was attributed to sandstone sedimentary rocks since they are the most porous, and given their essentially quartz composition, they possess less cohesion. On the other hand, cohesive rocks, such as silicified sandstone of the Botucatu Formation and basalt, received lower weightings, since they favor the surface runoff of water over the surface of the earth to the detriment of infiltration. 


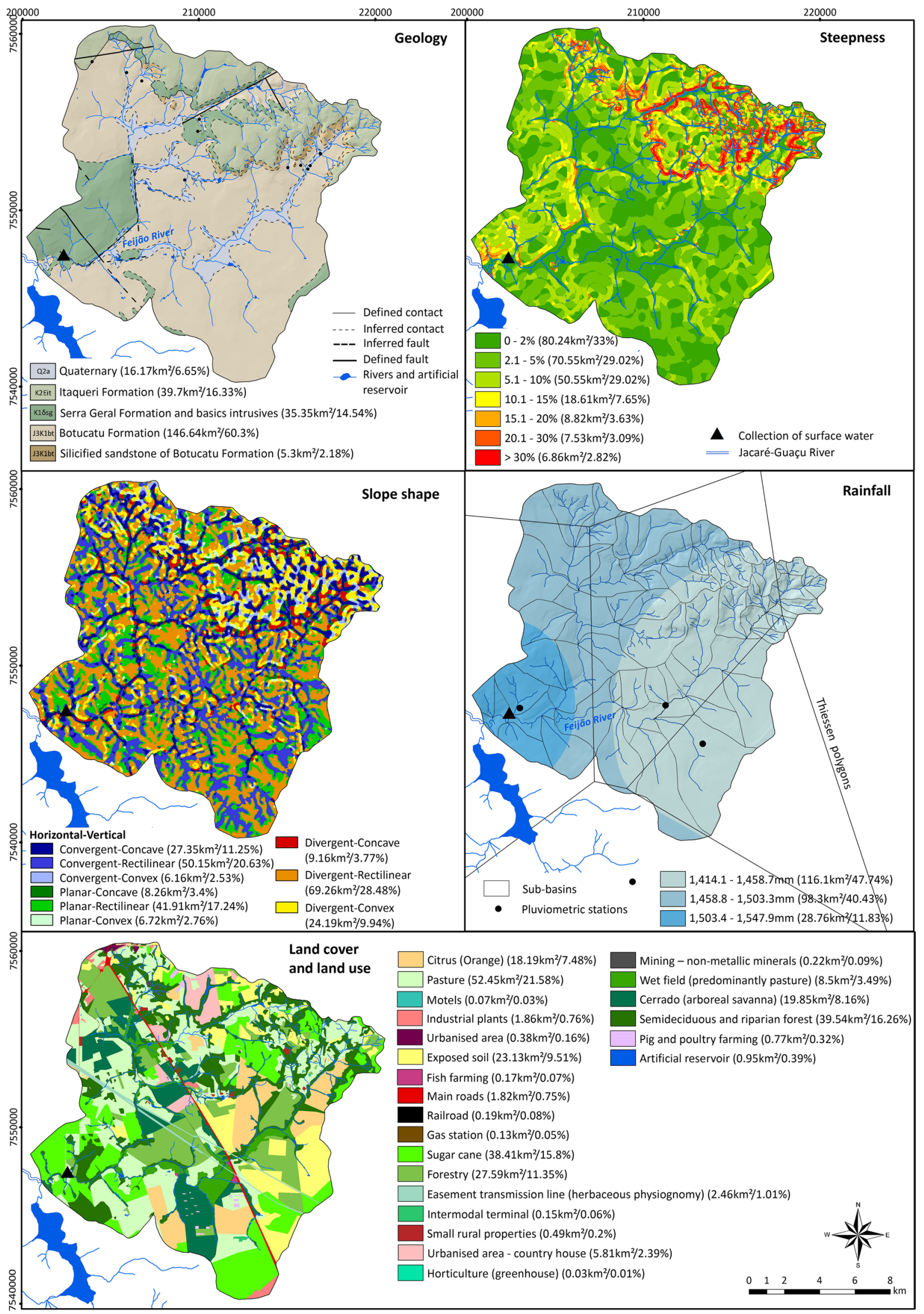

Fig. 2 Geoenvironmental attributes used in the analytic process 

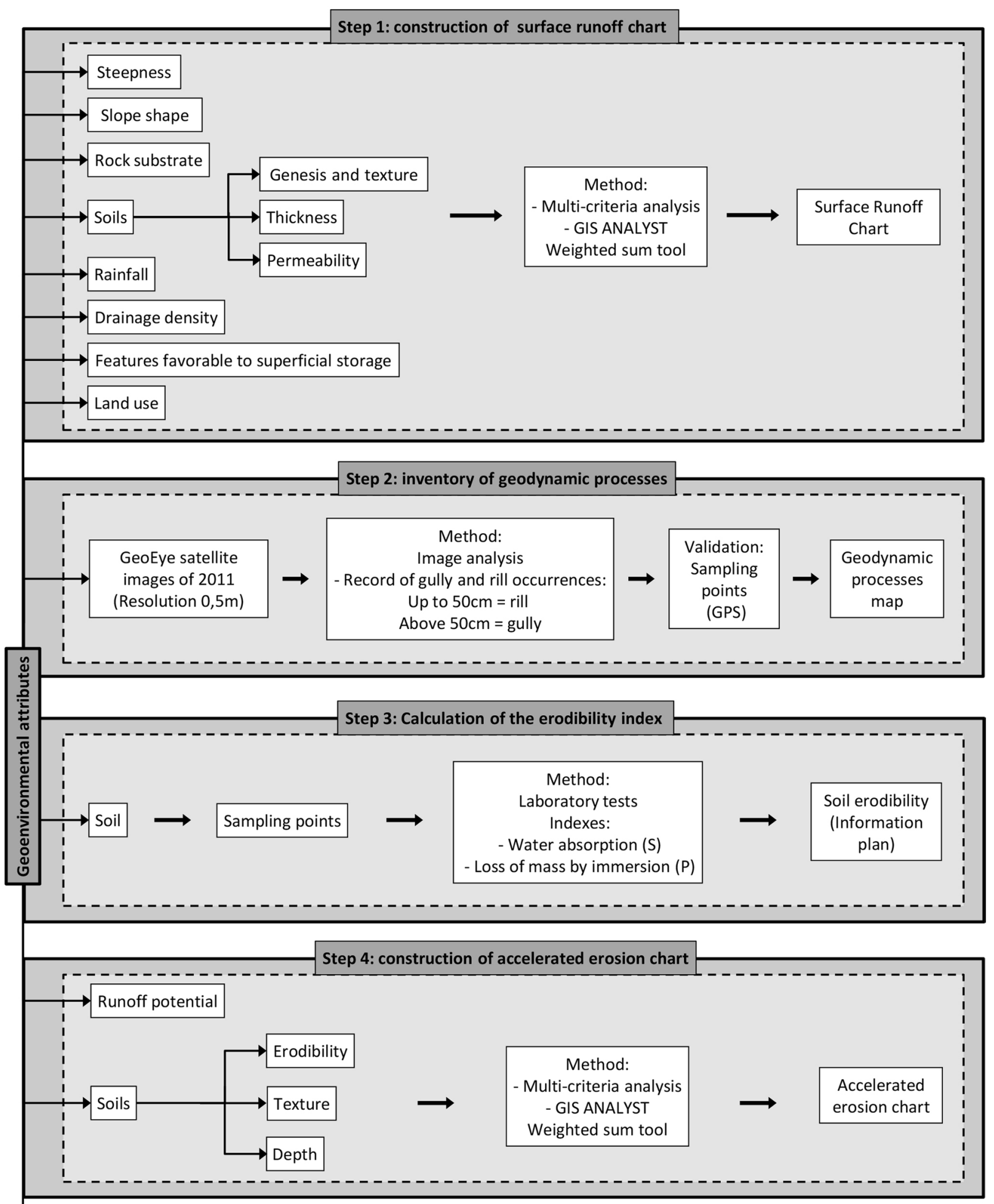

Step 5: overlay of geodynamic processes on the surface runoff and accelerated erosion charts

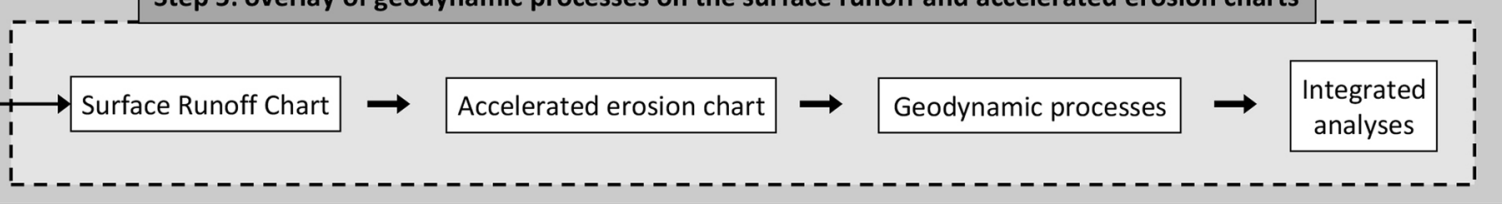

Fig. 3 Methodology flowchart used in this study 
Table 3 Schematic model and analytic treatment of the controlling geoenvironmental attributes for surface runoff processes

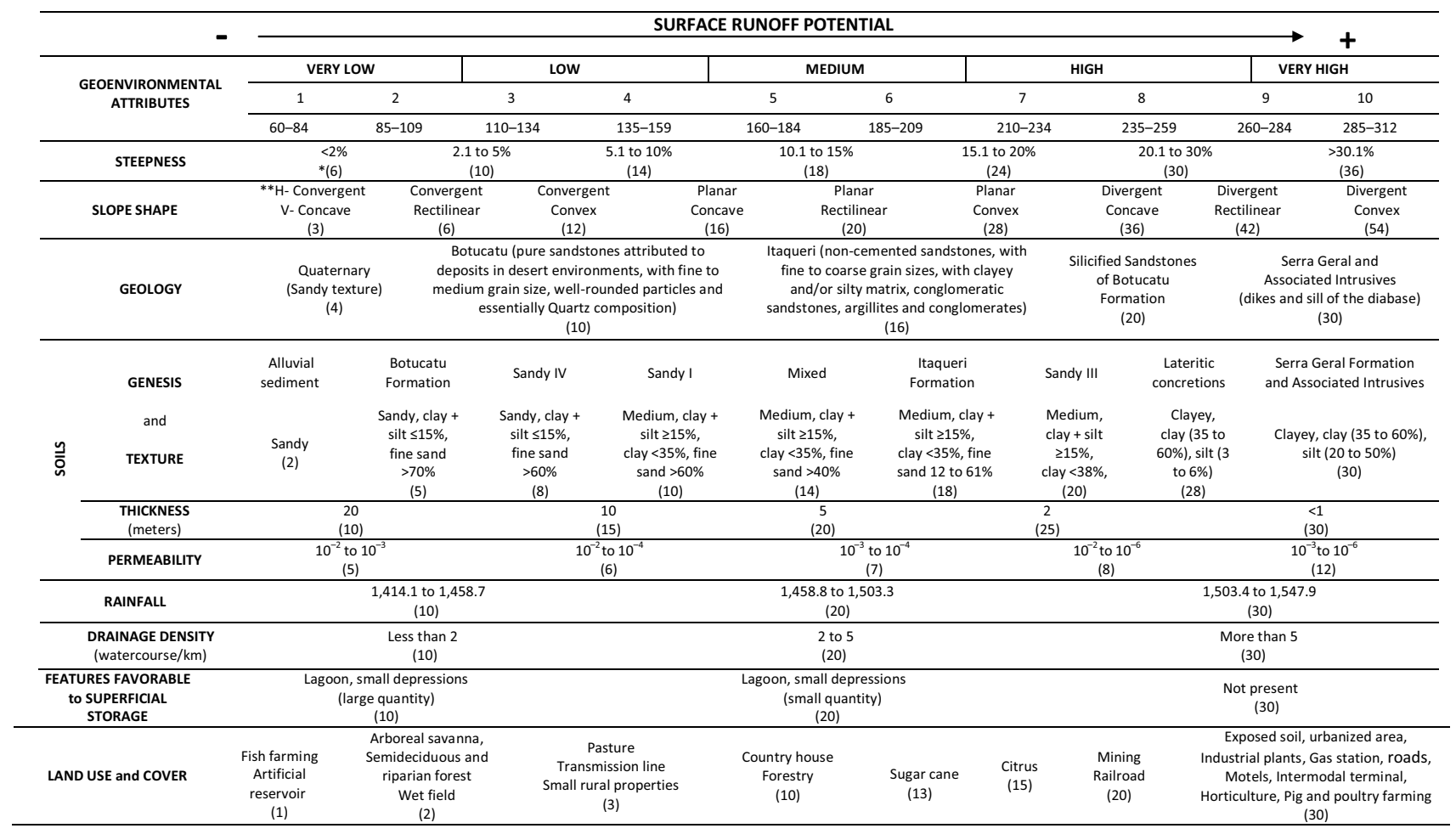

*() weight; ** $H$ horizontal, $V$ vertical

Table 4 Process utilized in the elaboration of the chart for accelerated erosion potential

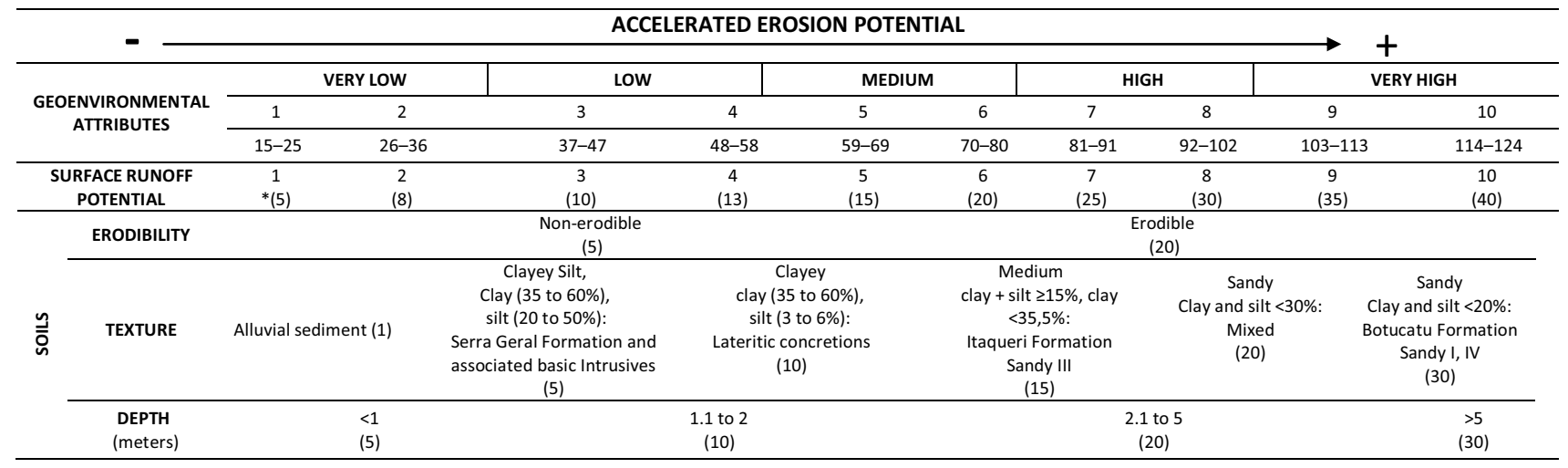

*() weight

Physical properties, principally structure, texture and permeability, typify the behavior of each soil equally in terms of relief, rainfall and soil cover and use (Bertoni and Lombardi Neto 2012). In this case, surface runoff of fine particle soils with lower permeability coefficients was considered more favorable.

Due to the slight variation in precipitation across the area and the fact that there is no totally dry season during the year (Mendonça and Danni-Oliveira 2007), rainfall data were divided into three classes with equal intervals.
Regions showing greater precipitation volumes received greater weightings.

The number of canals per kilometer is important in evaluating the runoff process, given that the faster the water reaches the canals, the greater the surface runoff potential will be (Pejon 1992). In this study, the basin area was divided into 58 sub-basins, with the greatest weighting being attributed to sub-basins that presented 5 or more perennial canals per linear kilometer, since each slope would be, on average, $100 \mathrm{~m}$ in length. Sub-basins with 2 or fewer canals 
per kilometer received a lower weighting, since the length of the slope can reach $500 \mathrm{~m}$. Each sub-basin was analyzed using two transects in perpendicular directions, adopting the one which presented the highest value.

Vegetation cover plays a role in slowing the impact of pluvial waters on the soil in terms of increasing infiltration capacity (Florenzano 2008). In areas with a high density of vegetation cover, surface runoff and erosion can occur at lower levels (Guerra and Cunha 2003).

Therefore, anthropogenic activities, which increase surface runoff and result in areas of exposed soils such as urbanized areas, highways and agricultural areas that include citriculture and sugar cane, received greater weighting values. On the other hand, Cerrado, semi-deciduous forests and riparian zones received lower weightings, followed by pastures and forestry plantations.

For the calculation of the erodibility index $\left(E_{40}\right)$, which integrated the potential for accelerated erosion assessment model, laboratory tests to determine the water absorption index $(S)$ as well as index of the loss of mass by immersion $(P)$ were carried out, according to the methodology proposed by Nogami and Villibor (1979), and these indexes were adapted to regional conditions by Pejon (1992).

A graph of water absorption during time $(t)$ by unit of area of the base of the test body $(q)$ was used to calculate the absorption index $(S)$. The square root of the time of the test is $(\sqrt{ } t)$. The index $S$ is the coefficient of the right angle, according to Eq. 1:

$S=\frac{q}{\sqrt{ } t}$

After the carrying out the water absorption test $(S)$, the test for the loss of mass by immersion $(P)$ was performed. In this case, the percentage of dislodged soil $(\% P)$ is the ratio between the dislodged mass and the initial soil mass (Eq. 2):

$\% P=\frac{\left(m_{i}-m_{f}\right)}{m_{i}} * 100$

where $m_{i}$ is the initial soil mass and $m_{f}$ is the final soil mass.

For the calculation of the erodibility index $\left(E_{40}\right)$, Eq. 3 was used:

$\left(E_{40}\right)=\frac{(40 * S)}{P}$

where $S$ means water absorption index and $P$ is the index for mass lost by immersion.

If $E_{40}<1$, it was considered that the material possessed high erodibility. If $\left(E_{40}\right)>1$, the material was classified as having low erodibility.

The quaternary geodynamic processes were mapped based on the interpretation of high resolution spatial satellite images (GeoEye satellite images of 2011, resolution $0.5 \mathrm{~m}$ ) and of validation and supervision in loco. Geodynamic processes up to $50 \mathrm{~cm}$ width and depth were rills. Geodynamic processes above $50 \mathrm{~cm}$ in width and depth were gullies (SÃO PAULO-IPT 1989).

The map with the quaternary geodynamic processes was superimposed on the surface runoff and accelerated erosion potential charts to assess the spatial correlation between the geographic data.

\section{Results and discussion}

\section{Erodibility index}

Table 5 presents the erodibility index values $\left(E_{40}\right)$ of the soils from the laboratory test.

A total of 22 samples were verified, with 21 samples considered non-erodible $\left(E_{40}>1\right)$ and only one sample considered as erodible $\left(E_{40}<1\right)$. Therefore, the units of soils were classified as being of low erodibility. It is important to note that the soils are principally porous, sandy materials, which come apart easily when in contact with water, explaining some cases of high indexes of mass loss by immersion $(P)$.

\section{Surface runoff potential}

Based on the methodology adopted, the nine hierarchical levels obtained as results for potential surface runoff are presented in Fig. 4, combined with 400 localized geodynamic processes (rills and gullies) mapped in the study area.

The basin did not present a large proportion of areas with a high potential for surface runoff. Together, classes 2, 3, 4 and 5 made up $89.79 \%$ of the area. This significant percentage of low to medium surface runoff potential is intrinsically related to the morpho-structural and lithological characteristics of the Paraná Basin, which is primarily made up of sandstone rocks covered by soils with a sandy texture in areas with low steepness.

Additionally, it was verified that the classes of potential surface runoff varied in the area with outcrops of the same lithology due to the differences in terms of other geoenvironmental attributes.

In the area with the Botucatu Formation cover (essentially quartz sandstones that have well-rounded grains and high porosity and that are very friable) in the form of extensive sedimentary surfaces (Fig. 2), lower indexes of surface runoff were found (classes 1-4). In these areas, sandy (fine sand $>60 \%$ ) and deep (from 10 to $20 \mathrm{~m}$ ) soils predominated that also had high permeability coefficients $\left(10^{-3}-10^{-2} \mathrm{~cm} / \mathrm{s}\right)$ (Table 1). There was homogeneity in the relief, which is flat (steepness $<2 \%$ ) or lightly undulating (steepness $<10 \%$ ), 
Table 5 Results of the erodibility test

\begin{tabular}{|c|c|c|c|c|c|c|c|c|}
\hline \multirow[b]{2}{*}{ Soils } & \multicolumn{8}{|c|}{ Erodibility test } \\
\hline & Sample & Thickness (m) & $S^{*}$ & $S(\bar{x})$ & $P(\%)$ & $P(\%)(\bar{x})$ & $E_{40}$ & $E_{40}(\bar{x})$ \\
\hline \multicolumn{9}{|l|}{ Residuals } \\
\hline \multirow[t]{2}{*}{ Botucatu Formation } & $5 \mathrm{~A}$ & 0.4 & 2.51 & 3.03 & 7.2 & 26.65 & 13.92 & 8.51 \\
\hline & $5 \mathrm{~B}$ & 0.8 & 3.56 & & 46.1 & & 3.09 & \\
\hline \multirow{2}{*}{$\begin{array}{l}\text { Serra Geral Formation and } \\
\text { basic intrusive }\end{array}$} & $11 \mathrm{~A}$ & 1.4 & 2.59 & 2.48 & 57.4 & 63.9 & 1.8 & 1.58 \\
\hline & $11 \mathrm{~B}$ & 1.8 & 2.37 & & 70.4 & & 1.35 & \\
\hline \multirow[t]{2}{*}{ Itaqueri Formation (Sandy) } & $10 \mathrm{~A}$ & 0.7 & 2.63 & 2.45 & 4.9 & 11.9 & 21.66 & 13.23 \\
\hline & $10 \mathrm{~B}$ & 1.1 & 2.26 & & 18.9 & & 4.79 & \\
\hline \multicolumn{9}{|l|}{ Sediments } \\
\hline \multirow[t]{4}{*}{ Sandy I } & $1 \mathrm{~A}$ & 2.2 & 0.24 & 1.77 & 10.8 & 6.08 & 0.87 & 32.7 \\
\hline & $1 \mathrm{~B}$ & 3 & 1.93 & & 8.7 & & 8.84 & \\
\hline & $4 \mathrm{~A}$ & 0.5 & 2.47 & & 3.8 & & 26.29 & \\
\hline & $4 \mathrm{~B}$ & 1 & 2.45 & & 1 & & 94.79 & \\
\hline \multirow[t]{2}{*}{ Sandy III } & $8 \mathrm{~A}$ & 0.2 & 1.94 & 1.42 & 0.9 & 1.15 & 86.32 & 56.07 \\
\hline & $8 \mathrm{~B}$ & 0.6 & 0.9 & & 1.4 & & 25.81 & \\
\hline \multirow[t]{2}{*}{ Sandy IV } & $6 \mathrm{~A}$ & 1.1 & 3.07 & 3.07 & 56.9 & 65.85 & 2.16 & 1.9 \\
\hline & $6 \mathrm{~B}$ & 2.1 & 3.06 & & 74.8 & & 1.64 & \\
\hline \multirow[t]{4}{*}{ Mixed } & $2 \mathrm{~A}$ & 0.5 & 1.78 & 2.78 & 5.8 & 55.55 & 12.34 & 4.51 \\
\hline & $2 \mathrm{~B}$ & 1 & 3.42 & & 47.7 & & 2.87 & \\
\hline & $3 \mathrm{~A}$ & 1 & 3.03 & & 83.6 & & 1.45 & \\
\hline & $3 \mathrm{~B}$ & 1.5 & 2.9 & & 85.1 & & 1.36 & \\
\hline \multirow[t]{2}{*}{ Lateritic concretions } & $9 \mathrm{~A}$ & 1.4 & 1.13 & 1.04 & 4.4 & 7.05 & 10.37 & 7.16 \\
\hline & $9 \mathrm{~B}$ & 1.5 & 0.95 & & 9.7 & & 3.94 & \\
\hline \multirow[t]{2}{*}{ Alluvial } & $7 \mathrm{~A}$ & 0.4 & 0.45 & 0.43 & 0.5 & 0.4 & 33.32 & 41.2 \\
\hline & $7 \mathrm{~B}$ & 0.4 & 0.4 & & 0.3 & & 49.07 & \\
\hline
\end{tabular}

disposed in elongated interfluvial areas and diverging slopes (rectilinear and convex).

In terms of geological formation units, land use and land cover are mainly related to profitable agricultural activities, such as cattle grazing, forestry plantations, sugar cane and citrus, as well as areas made up of semi-deciduous and riparian forests, Cerrado and wet fields. These land uses and land covers favor infiltration, given that vegetation reduces the speed of hydraulic flow, thus increasing retention and reducing flash flooding peaks.

Such a combination of geoecological attributes, observed in many basins, means that surface runoff in the direction of the canals is reduced. Therefore, the capacity of capture and infiltration originating from precipitation is intensified. In loco, it is found that the lower density of drainage canals that run through the Botucatu Formation sustain an elevated capacity for infiltration.

On the other hand, the worst scenario that can occur due to these residual sandy soils from the Botucatu Formation is the total removal of vegetation, leaving the earth uncovered. Considering the total annual rainfall of the area

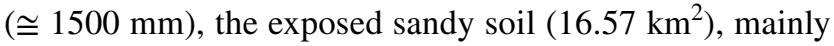
in the preparation phase for the cultivation of sugar cane, intensifies surface runoff and, consequently, results in accelerated erosion. Additionally, exposed sandy soil increases the risk of water quality deterioration due to surface runoff and pollutants washing into the drainage network.

Over Botucatu Formation, Quaternary alluvial deposits occur in an elongated and at times spread out manner over the regions at the bottom of the valleys of the main water courses, constituting the inundation plains of the rivers. These plains (steepness $<2 \%$ ) are mainly surrounded by convergent slopes (concave and rectilinear) and were, throughout the years, covered by sandy sediments due to the contribution of adjacent geology. Due to such physical characteristics, these alluvial areas present low surface runoff potential (classes 1-4), favoring the accumulation and dispersal of water.

It is necessary to note that, in situ, on these alluvial plains, a humid zone forms, in which the water presents itself almost superficially, including during the driest part of the year. Given this, though the phreatic surface can undergo variations throughout drought periods, these areas remain green, being fed under the surface by the slow release of infiltrated rainwater in topographically more elevated areas. 


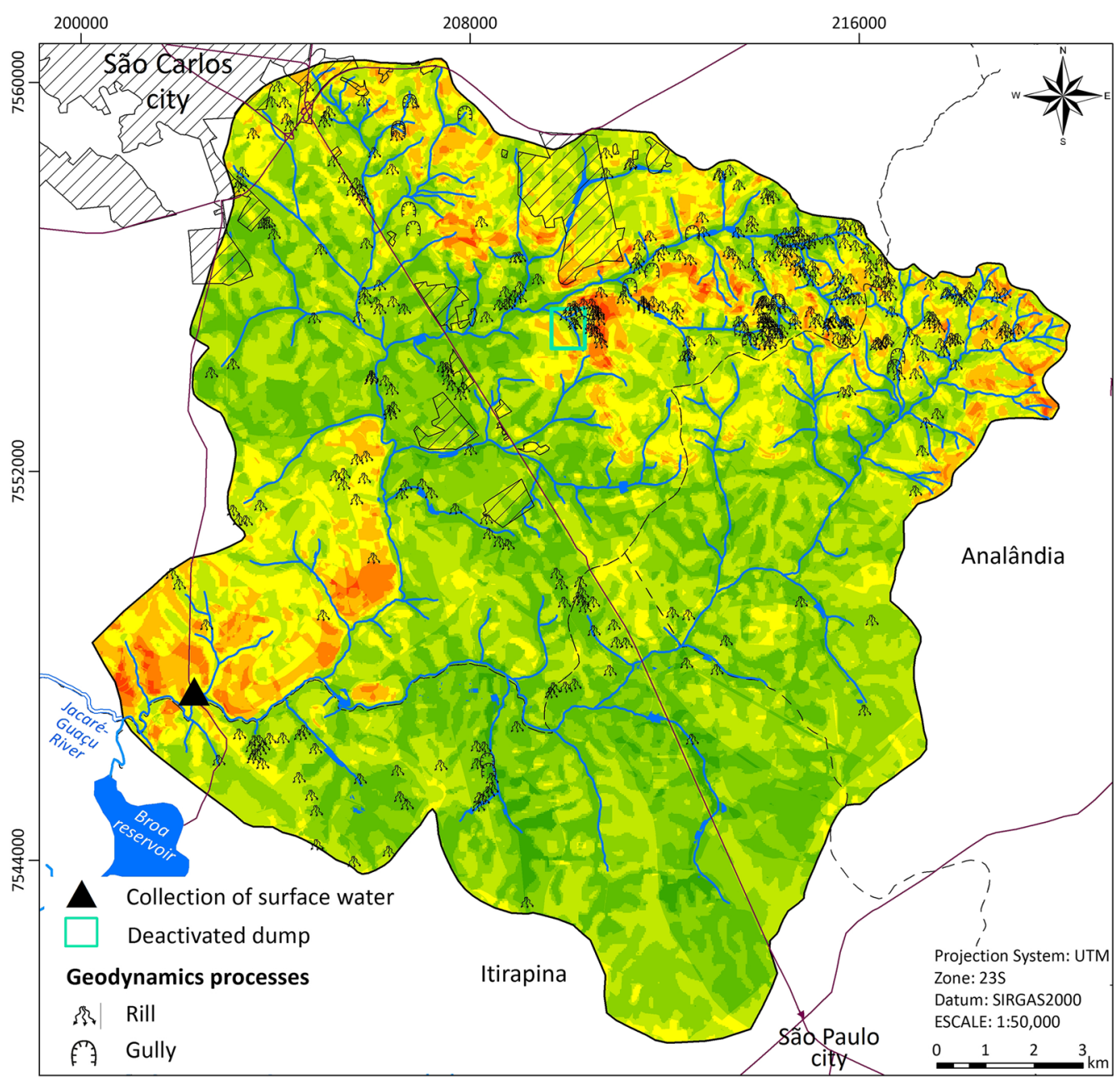

Geodynamics processes

Runoff

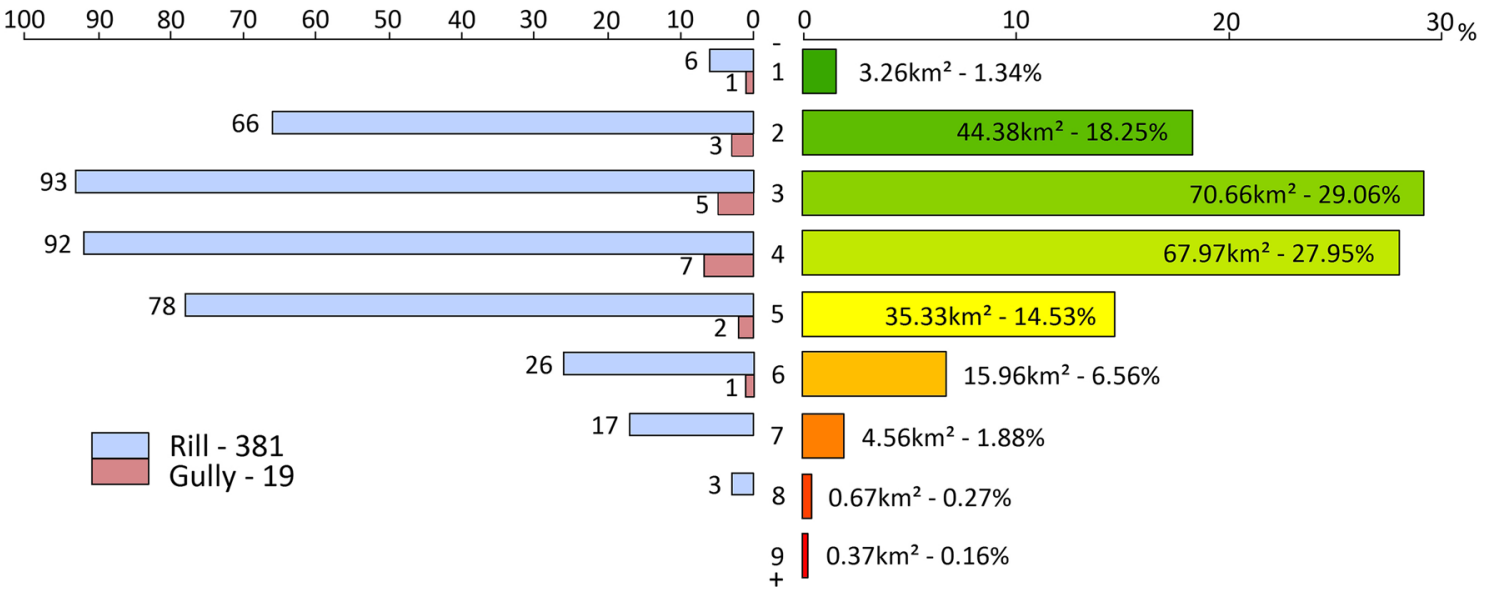

Fig. 4 Surface runoff potential chart and active accelerated erosive processes representation in the Feijão River basin

In the areas where the Itaqueri Formation (noncemented arenite of fine to coarse particles, sandstone conglomerates), which occupies the more elevated portions of the basin on the back of the arenitic-basaltic cuestas
(N-NE), occurs, a predominance of very low to medium (2-5) surface runoff classes was found. Such an area shows conditions favorable for infiltration, given that median-textured, well-developed soils predominate, with a thickness 
on the order of $10 \mathrm{~m}$, steepness less than $15 \%$ and permeability coefficients that vary from $10^{-6}$ to $10^{-2} \mathrm{~cm} / \mathrm{s}$.

In these summit zones, the presence of numerous springs can be observed. These springs occur due to rainwater infiltration into the soil. The inclined surface of the summit meets resistance from the rocky bulk, from this point, part of the water infiltrates the soil, and the other part moves laterally to the contact area of soil/rock, emerging at lower altitudes in the emerging forms. Subsequently, first-order canals are formed, which run along the elevated levels on the slopes.

In contrast to this scenario, the areas of Itaqueri Formation located in the extreme NE of the study area, in more accentuated classes of steepness ( $>15 \%)$, favored surface runoff and presented more elevated indexes (classes 5-8).

For the areas where low-permeability rocks (such as the Serra Geral Formation) and associated basic intrusive rocks (basalt and diabase dikes and sills) were encountered, higher values for potential surface runoff were identified, varying from medium to high (classes 5-9).

In the areas classified as high to very high and therefore presenting limited conditions for infiltration, it was found that the soils possessed the lowest permeability coefficients, reaching $10^{-6} \mathrm{~cm} / \mathrm{s}$, were thinner (from 2 to $5 \mathrm{~m}$ ) and had finer textures (clay between 35 and $60 \%$ and silt between 20 and 50\%). In these areas, steepness classes greater than 15\% and divergent slope shapes (rectilinear and convex), which do not favor infiltration, predominate. In terms of land cover and use, a dominance of sugar cane cultivation followed by pasture was observed. Such a scenario impacts numerous accelerated erosive processes such as rills and gullies, concentrated in the center north region of the basin.

Surface runoff potential was low to medium (classes 4 and 5) in areas where the silicified sandstone associated with the Botucatu Formation (flanking escarpments of the sandstone Cuestas) emerged. Despite being observed in areas with a steepness above $30 \%$, which also explains the decrease in thickness of the laid soils $(<2 \mathrm{~m})$, this result was conditioned mainly by the presence of semi-deciduous forests, which lined the margins of the slopes in topographical spaces where it is practically impossible for human activity to occur.

In these areas, the forest played the role of slowing the impact of the pluvial water mass, resulting in a reduction in the speed of the flow and in an increase in infiltration capacity, mainly when the water mass reached the lower concave continuation of the slopes, occupied by sandy soils and arranged in the form of colluvial ramps.

A strong spatial correlation was found between the mapped erosive processes (124 rills and 3 gullies) (Fig. 4) and the higher classes of potential for surface runoff (classes from 5 to 8, from medium to high) for the accelerated erosive processes located mainly in the more elevated areas (in the NE portion of the studied area). The main factor for this concentration of accelerated erosive processes in this region is the degree of steepness ( $>15 \%)$ and the use of soils for pastures overlaid on the Itaqueri Formation.

On the other hand, a large quantity of accelerated erosive processes (251 rills and 15 gullies) were located in areas with very low to low surface runoff potential (2, 3 and 4$)$ and interspersed throughout an extensive section in the NE-SW direction of the basin. In this case, the influence of surface runoff on erosive potential was not decisive, being more associated with physical characteristics, such as the weak degree of cohesion of the Botucatu Formation, as well as soil use in terms of pastureland and sugar cane.

\section{Accelerated erosion potential}

The study area mainly showed a moderate potential for development of accelerated erosion, based on the extensive areas with classes 5 and 6 that occupied $86.12 \%$ of the basin. Additionally, the comparison of the accelerated erosion potential chart with the mapped geodynamic processes (rills and gullies) showed satisfactory results, with good spatial correlation, once a significant part of the erosive processes was concentered in high-potential areas (Fig. 5).

Lower accelerated erosion potential (classes 1 and 2 in Fig. 5) occurred in areas occupied by the Quaternary alluvial deposits, which presented low water absorption $(S)$ and a low value for loss of mass by immersion, only $0.4 \%(P)$. It is worth noting that the quantity of organic material was visibly elevated.

In situ, in these areas of wet fields, corridors of herbaceous species provide conditions for extensive livestock activities. According to Trimble and Mendel (1995), such anthropogenic activities function as a trigger for accelerated erosive processes, even in situations with a low potential for surface runoff, due to trampling and the resulting compaction of the soil by the livestock. In these areas, 14 rills were mapped.

Classes 3 and 4 represent a low potential to develop accelerated erosive processes, being associated with areas covered by native vegetation and clay soils (clay between 35 and $60 \%$ and silt between 20 and 50\%), derived from lithology as matrix composed by fine material, as is the case with the Serra Geral Formation, and correlated as basic intrusive.

In this case, despite the unity of the present non-consolidated materials and the elevated loss of mass by immersion $(P \bar{x}=63.9 \%)$, the presence of arboreal vegetation and soils with fine soil particles hampered the disaggregation and surface runoff of the soil particles, naturally controlling the incision of the soils. Given this result, 55 rills and 5 gullies were mapped in non-forested locations.

The erosion accelerated potential of class 5 is on the surfaces of summits in the back of the cuestas, where 


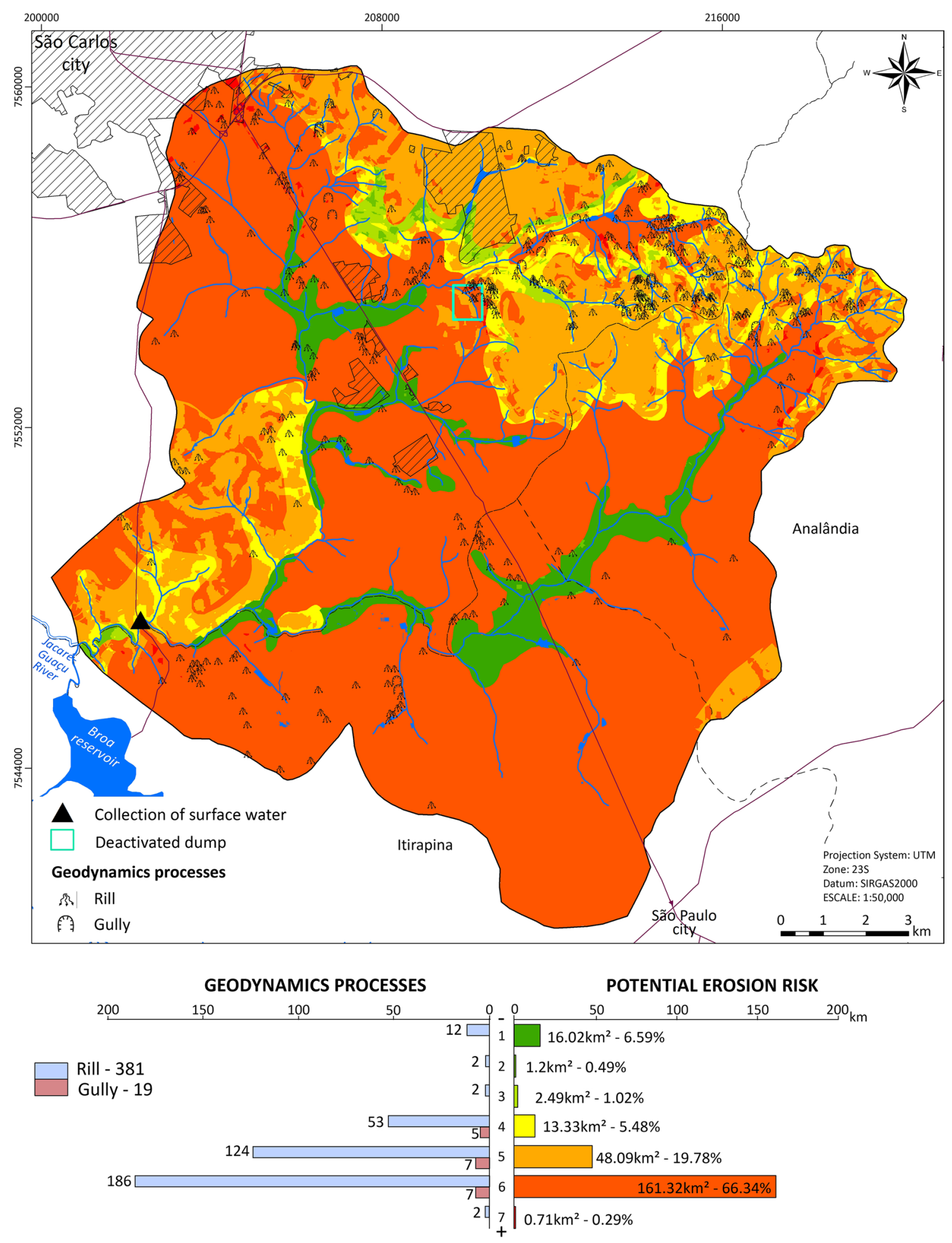

Fig. 5 Chart of potential for accelerated erosion and Quaternary geodynamic processes spatialized in the Feijão River basin

soils with an average texture are found (clay + silt $\geq 15 \%$, clay $<35.5 \%$ ), which are residues from the Itaqueri Formation. In the SW part of the region from the basin, there is an area where clayey/silty soils are found (clay between
35 and 60\%, silt between 20 and 50\%) from the Serra Geral Formation and are basic intrusive. In this class, 124 rills and 7 gullies were mapped, which were mainly associated 
with pastureland, sugar cane and areas of exposed soil during the preparation phase for sugar cane cultivation.

The regions with greatest potential for accelerated erosion (classes 6 and 7) were mapped along a NW/SE and $\mathrm{NE} / \mathrm{SW}$ direction from the study area, where 188 rills and 7 gullies were found. This result is explained by the presence of sandy textured $(<20 \%$ of fine) and thick $(>5 \mathrm{~m})$ soils, originating from the in situ alteration of the Botucatu Formation (primarily quartz sandstone that has well-rounded grainsand high porosity and that is highly friable). As an aggravating factor, the overlaid land use and soil covering are predominately pastureland followed by sugar cane, forest plantations and exposed soil (preparation for the cultivation of sugar cane).

\section{Driving forces}

Table 6 clarifies the more specific relationships between the processes of accelerated erosion and the geoenvironmental attributes. This comparative analysis is important in the assessment of the current state of the geodynamic processes in the study area.

Extensive livestock was a direct driving force, acting as a trigger for accelerated erosive processes in the wellhead areas and representing $81.2 \%$ of the rill processes and $94.7 \%$ of the gully processes.

Despite these forms of incision normally occurring in the sections of greatest steepness and in minimally altered profiles (Bertoni and Lombardi Neto 2012), in the study area, these forms predominated in steepness from 0 to $10 \%$ in well-developed soils (between 10 and $20 \mathrm{~m}$ thickness) of elevated permeability $\left(10^{-3}-10^{-2} \mathrm{~cm} / \mathrm{s}\right)$.

Many accelerated erosive processes were verified (47.3\% of the rills and $42.1 \%$ of the gullies) in the portion of the area with the highest potential for accelerated erosion, where the Botucatu Formation emerges. In this case, the geodynamic processes developed because the silts had a sandy texture and were extensively used for livestock.

Evidence of more intense concentrated action from erosive processes (32.8\% rills and $36.8 \%$ gullies) was found together with the Itaqueri Formation, the region in which there is a moderate potential for accelerated erosion in NE of the basin. These processes are conditioned by the sandy texture of the soil, greater steepness of the land and the greater potential for surface runoff. It is worth noting that, in this area, the greatest number of springs and first-order canals in the basin were observed. In this case, the eroded soils in the form of particulate material tend to enter these water bodies, which are very vital to the maintenance of water quantity and quality of the headwaters of the catchment, thereby degrading them.

In these cases, both in the outcropping of the Botucatu Formation and in that of the Itaqueri Formation, it was
Table 6 Geoenvironmental attributes related to accelerated erosive process development

\begin{tabular}{|c|c|c|c|c|}
\hline \multirow[t]{2}{*}{ Geoenvironmental attributes } & \multicolumn{4}{|c|}{ Geodynamics processes } \\
\hline & Rill & $\%$ & Gully & $\%$ \\
\hline \multicolumn{5}{|l|}{ Land use and cover } \\
\hline Pasture & 309 & 81.2 & 18 & 94.7 \\
\hline Deactivated dump—currently pasture & 23 & 6 & 1 & 5.3 \\
\hline Sugar cane & 26 & 6.8 & & \\
\hline Citrus (Orange) & 6 & 1.6 & & \\
\hline Forestry & 7 & 1.8 & & \\
\hline Exposed soil & 3 & 0.8 & & \\
\hline Urbanized area & 5 & 1.3 & & \\
\hline Cerrado (arboreal savanna) & 2 & 0.5 & & \\
\hline Total & 381 & $100 \%$ & 19 & $100 \%$ \\
\hline \multicolumn{5}{|l|}{ Geological units } \\
\hline Botucatu & 180 & 47.3 & 8 & 42.1 \\
\hline $\begin{array}{l}\text { Silicified sandstone of Botucatu Forma- } \\
\text { tion }\end{array}$ & 11 & 2.9 & 1 & 5.3 \\
\hline Itaqueri & 125 & 32.8 & 7 & 36.8 \\
\hline Serra Geral and basic intrusive & 52 & 13.6 & 3 & 15.8 \\
\hline Quaternary & 13 & 3.4 & & \\
\hline Total & 381 & $100 \%$ & 19 & $100 \%$ \\
\hline \multicolumn{5}{|l|}{ Soils } \\
\hline Botucatu Formation & 133 & 34.9 & 9 & 47.3 \\
\hline $\begin{array}{l}\text { Serra Geral Formation and basic intru- } \\
\text { sive }\end{array}$ & 24 & 6.3 & & \\
\hline Itaqueri Formation (Sandy) & 83 & 21.8 & 6 & 31.6 \\
\hline Sandy I & 30 & 7.9 & & \\
\hline Sandy III & 3 & 0.8 & & \\
\hline Sandy IV & 48 & 12.6 & 3 & 15.8 \\
\hline Mixed & 10 & 2.6 & & \\
\hline Lateritic concretions & 37 & 9.7 & 1 & 5.3 \\
\hline Alluvial sediment & 13 & 3.4 & & \\
\hline Total & 381 & $100 \%$ & 19 & $100 \%$ \\
\hline \multicolumn{5}{|l|}{ Thickness } \\
\hline$<1 \mathrm{~m}$ & 13 & 3.4 & & \\
\hline $2 \mathrm{~m}$ & 38 & 10 & 5 & 26.3 \\
\hline $5 \mathrm{~m}$ & 17 & 4.5 & & \\
\hline $10 \mathrm{~m}$ & 220 & 57.7 & 12 & 63.2 \\
\hline $20 \mathrm{~m}$ & 93 & 24.4 & 2 & 10.5 \\
\hline TOTAL & 381 & $100 \%$ & 19 & $100 \%$ \\
\hline \multicolumn{5}{|l|}{ Steepness } \\
\hline $0-2 \%$ & 98 & 25.7 & 5 & 26.4 \\
\hline $2-5 \%$ & 52 & 13.6 & 2 & 10.5 \\
\hline $5-10 \%$ & 74 & 19.4 & 2 & 10.5 \\
\hline $10-15 \%$ & 54 & 14.2 & 2 & 10.5 \\
\hline $15-20 \%$ & 51 & 13.4 & 4 & 21.1 \\
\hline $20-30 \%$ & 30 & 7.9 & 2 & 10.5 \\
\hline$>30 \%$ & 22 & 5.8 & 2 & 10.5 \\
\hline Total & 381 & $100 \%$ & 19 & $100 \%$ \\
\hline \multicolumn{5}{|l|}{ Slope shape } \\
\hline Convergent concave & 88 & 23.1 & 8 & 42.1 \\
\hline
\end{tabular}


Table 6 (continued)

\begin{tabular}{lllll}
\hline Geoenvironmental attributes & \multicolumn{5}{c}{ Geodynamics processes } \\
\cline { 2 - 6 } & Rill & $\%$ & Gully & $\%$ \\
\hline Convergent rectilinear & 76 & 19.9 & & \\
Convergent convex & 14 & 3.7 & 1 & 5.3 \\
Planar concave & 34 & 8.9 & 5 & 26.2 \\
Planar rectilinear & 38 & 10 & 1 & 5.3 \\
Planar convex & 11 & 2.9 & 1 & 5.3 \\
Divergent concave & 31 & 8.1 & 1 & 5.3 \\
Divergent rectilinear & 51 & 13.4 & 2 & 10.5 \\
Divergent convex & 38 & 10 & & \\
Total & 381 & $100 \%$ & 19 & $100 \%$ \\
\hline
\end{tabular}

verified that accelerated erosive processes are intensified when pastureland for extensive livestock grazing occupies the convergent/concave hill segments $(23.1 \%$ of the rills and $42.1 \%$ of the gullies) and the convergent/rectilinear (19.9\% of the rills) slopes.

The most harmful effects of livestock grazing on the landscape are well defined by Trimble and Mendel (1995). According to these authors, livestock is an important agent for geomorphological change. In the steepest areas of the land, livestock move upward, exerting significant force ( $\cong 2500 \mathrm{kPa})$ on the soil, resulting in compaction and reducing infiltration, further increasing surface runoff and accelerating erosive processes.

Due to the nature of livestock, they can be present on a range of lands, even in the areas of wet fields of the basin in low steepness. In this case, the marginal alluvial deposits of the water courses (Quaternary) are susceptible to developing rills, since they provide access to water sources for watering the livestock.

Soils with temporary cultivation crops such as sugar cane are more vulnerable to erosion than soils with perennial or semi-perennial plants (Bertoni and Lombardi Neto 2012). In the cultivation of sugar cane, the intensive use of heavy agricultural machinery and piping on a large scale for irrigation leads to compaction and clogging of the soil pores reducing infiltration, which consequently increases surface runoff and accelerates erosion, as highlighted by Dorici et al. (2016).

In the study area, 26 rills (6.8\%) were mapped in areas intended for the cultivation of sugar cane. The predominance of these processes in areas that did not have soil conservation management practices, such as contour lines and terracing, was observed. The simple adoption of conservation practices could reduce surface runoff, which would lead to a clear reduction in the supply of sediments and effluent into the Feijão River. This situation was clearly observed when comparing sugar cane cultivation in leasing systems and areas of cultivation on agroindustry properties. We observed fewer conservation practices being applied in leased sugar cane cultivation areas than on agroindustry land properties.

Only at the deactivated landfill (Fig. 5) was the occurrence of 23 rills recorded (6\%), and a gully of large dimensions was reported. In situ, these processes are explained by land destruction for trash compaction in the past and by the current land cover and uses being intended for breeding of buffalo. When moving around, these heavy animals exert great vertical force on the soil, increasing the development of accelerated erosive processes.

\section{Territorial planning strategies to positively impact the hydric resources}

In this study, significant recent geodynamic processes were identified in an area of peri-urban headwaters of a catchment located in the southeast region of Brazil. It is important for us to suggest some basic guidelines to reconcile economic development and the preservation of ecosystem services provided by the basin, especially in terms of the surface and subterranean provision of good quality water.

- In the summit areas, where the Itaqueri Formation occurs, livestock should be prevented from accessing all sources of the water courses in that area, which are arranged in the form of an amphitheater, mainly in the convergent/concave segments, with the aim of avoiding trampling and compaction and consequently the triggering of erosive processes.

- It is necessary to restore the natural vegetation areas in the interfluves, mainly on the surface of the summit in the areas where higher surface runoff was found. Thus, vertical water flow can be intensified, feeding the springs and aquifers downstream.

- Advocates for the obligatory protection of wet field areas of up to $10 \mathrm{~m}$ in width want these areas to serve as natural filters that can contain the sedimentation originating from the more elevated zones, mainly where there is sugar cane cultivation. It is expected that such measures will also mitigate the diffuse pollution carried with the surface runoff.

- There is a need for the creation of priority zoning for the restoration of degraded areas.

Not following the proposed guidelines may intensify the development of accelerated erosive processes and lead to negative consequences for water storage. 


\section{Conclusions}

A large part of the studied area presented a low potential for surface runoff. In terms of the potential of accelerated erosion, $86.12 \%$ of the basin surface showed a moderate potential due to the extensive amount of class 5 and 6 areas.

These results were unsurprising and showed that accelerated erosive processes are triggered by changes in the natural condition of soil cover; that is, there is a direct relation between the removal of primitive vegetation cover and the implementation of anthropogenic activities. In this case, extensive livestock grazing was found to be the main driving force for accelerated erosive processes, since $81.2 \%$ of the rills and $94.7 \%$ of the gullies occurred within livestock areas. The predominance of the "non-erodible" classification for the majority of soil samples suggests that soil properties play a secondary effect, unlike the classical analysis of erosion potential considers.

Sugar cane cultivation is the other important trigger for the development of erosion processes mainly when sugar cane cultivation occurs on leasing areas, as agroindustry does not apply conservationist techniques in these areas because they are rural properties.

The application of a low-cost, simplified method in this study showed the possibility of distinguishing areas where water flow tends to favor erosive processes and areas where water flow tends to infiltrate, feeding the surface water bodies and providing the replenishment of the hydro-ecological units in the basin.

The approach used in the present study is capable of being extended to other wellheads with equivalent natural conditions in the vast areas of the Brazilian southeast.

Acknowledgements The authors wish to thank Coordination for the Improvement of Higher Education (CAPES) and National Council for Scientific and Technological Development $(\mathrm{CNPq})$ for supporting the development of this research.

\section{References}

Agência Nacional de Águas (ANA) (2016) Sistema de Informações Hidrológicas-Hidro Web. http://www.snirh.gov.br/hidroweb/. Accessed 18 June 2016 (in Portuguese)

Bayon G, Dennielou B, Etoubleau J, Ponzevera E, Toucanne S, Bermell S (2012) Intensifying weathering and land use in iron age Central Africa. Science 335:1219-1222. https://doi.org/10.1126/ science. 1215400

Bertoni J, Lombardi Neto A (2012) Conservação do solo. 8 ed. São Paulo: Icone. p 355 (in Portuguese)

Boardman J (2006) Soil erosion science: reflections on the limitations of current approaches. CATENA 68(2-3):73-86. https://doi. org/10.1016/j.catena.2006.03.007

Christofoletti A (1974) Geomorfologia. EDIUSP, São Paulo, p 149

Companhia de Pesquisa de Recursos Minerais (CPRM) (2016) Sistema de Informações de Águas Subterrâneas (SIAGAS). http://siaga sweb.cprm.gov.br/layout/pesquisa_complexa.php. Accessed 14 Nov 2016 (in Portuguese)

Costa CW, Dupas FA, Cespedes JG, Silva LF (2013) Monitoramento da expansão urbana, cenários futuros de crescimento populacional e o consumo de recursos hídricos na cidade de São Carlos, SP. Geociências 32(1):63-80 (in Portuguese)

Costa CW, Piga FG, Moraes MCP, Dorici M, Sanguinetto EC, Lollo JA, Moschini LE, Lorandi R, Oliveira LJ (2015) Fragilidade ambiental e escassez hídrica em bacias hidrográficas: Manancial do Rio das Araras-Araras, SP. Revista Brasileira de Recursos Hídricos 20(4):946-958 (in Portuguese)

Coulthard TJ, Hancock GR, Lowry JBC (2012) Modelling soil erosion with a downscaled landscape evolution model. Earth Surf Process Landf 37(10):1046-1055. https://doi.org/10.1002/ esp. 3226

Dorici M, Costa CW, Moraes MCP, Piga FG, Lorandi R, Lollo JÁ, Moschini LE (2016) Accelerated erosion in a watershed in the southeastern region of Brazil. Environ Earth Sci 75(1301):1-12. https://doi.org/10.1007/s12665-016-6102-7

Eigenbrod F, Anderson BJ, Armsworth PR, Heinemeyer A, Jackson SF, Parnell M, Thomas CD, Gaston KJ (2009) Ecosystem service benefits of contrasting conservation strategies in a human-dominated region. Proc R Soc B 276:2903-2911. https://doi.org/10.1098/ rspb.2009.0528

Environment Agency - (UK) (2002) Agriculture and natural resources: benefits, costs and potential solutions. Environment Agency, Bristol, p 102

ESRI (Environmental Systems Research Institute) (2011) World_ Imagery. Source: Esri, DigitalGlobe, GeoEye, i-cubed, USDA, USGS, AEX, Getmapping, Aerogrid, IGN, IGP, swisstopo, and the GIS User Community

ESRI (Environmental Systems Research Institute) (2013) ArcGIS for the desktop 10.2.2

Florenzano TG (Org) (2008) Geomorfologia: conceitos e tecnologias atuais. 1. ed. São Paulo: Oficina de Textos, p 318 (in Portuguese)

Food and Agriculture Organization of the United Nations (FAO) (2011) The state of the world's land and water resources for food and agriculture (SOLAW) - managing systems at risk. Food and Agriculture Organization of the United Nations, Rome and Earthscan, London

Fundação Sistema Estadual de Análise de Dados (SEADE) (2016) Informações dos Municípios Paulistas. http://www.imp.seade.gov. br/frontend/\#/tabelas. Accessed 14 Oct 2016

Galharte CA, Villela JM, Crestana S (2014) Estimativa da produção de sedimentos em função da mudança de uso e cobertura do solo. Revista Brasileira de Engenharia Agrícola e Ambiental 18(2):194-201 (in Portuguese)

Guerra AJT, Cunha SB (Org) (2003) Geomorfologia: uma atualização de bases e conceitos. 5. ed. Rio de Janeiro: Bertrand Brasil, p 472 (in Portuguese)

Guerra AJT, Fullen MA, Jorge MCO, Alexandre ST (2014) Soil erosion and conservation in Brazil. Anuário do Instituto de Geociências UFRJ 37(1):81-91

Hasui Y (2012) Compartimentação Geológica do Brasil. In: Hasui Y, Carneiro CDR, de Almeida FFM, Bartorelli A (Org.), Geologia do Brasil. São Paulo: BECA, pp 112-122 (in Portuguese)

Instituto Brasileiro de Geografia e Estatística (IBGE) (1971) Folha Topográfica de Corumbataí (SF-23-Y-A-I-2). Escala 1:50.000 (in Portuguese)

Instituto Brasileiro de Geografia e Estatística (IBGE) (1971b) Folha Topográfica de São Carlos (SF-23-Y-A-I-1). Escala 1(50):000 (in Portuguese)

Instituto Brasileiro de Geografia e Estatística (IBGE) (2005) Resolução $N^{o} 1 / 2005$. Estabelece o Sistema de Referência Geocêntrico para as Américas (SIRGAS). Brasília (in Portuguese) 
Instituto de Pesquisas Tecnológicas do Estado de São Paulo (IPT) (1981) Mapa Geomorfológico do Estado de São Paulo. São Paulo. v. 2. Escala 1:1.000.000

Instituto de Pesquisas Tecnológicas do Estado de São Paulo (IPT) (1989) Determinação de áreas críticas à erosão ao longo das faixas marginais dos reservatórios dos rios Tietê e Paranapanema. Relatório 26:769 (in Portuguese)

Instituto Geológico de São Paulo (IG) (1984) Folha Geológica de Corumbataí, São Paulo. Escala 1(50):000

Instituto Nacional de Pesquisas Espaciais (INPE) (2016) TOPODATA, banco de dados geomorfométricos do Brasil. http://www.dsr.inpe. br/topodata/index.php. Accessed 18 Oct 2016

Iritani MA, Ezaki S (2012) As águas subterrâneas do Estado de São Paulo. 3. ed. São Paulo: Secretaria de Estado do Meio Ambiente - SMA, p 104 (in Portuguese)

Kirkby MJ, Jones RJA, Irvine B et al (2004) Pan-European Soil Erosion Risk Assess-ment: The PESERA Map, Version 1 October 2003. Explanation of Special Publication Ispra 2004 No.73 (S.P.I.04.73). European Soil Bureau Re-search Report No.16, EUR 21176.18 p. and 1 map in ISO B1 format. Office for Official Publications of the European Communities, Luxembourg. http://citeseerx.ist.psu. edu/viewdoc/download?doi=10.1.1.397.1185\&rep=rep1\&type $=$ pdf. Accessed 17 Jan 2017

Lal R (1990) Soil erosion in the tropics: principles and management. McGraw-Hill, New York, p 580

Lollo JA, Sena JN (2013) Establishing erosion susceptibility: analytical hierarchical process and traditional approaches. Bull Eng Geol Environ 72(3-4):589-600

Machado FH, Mattedi AP, Dupas FA, Silva LF, Vergara FE (2016) Estimating the opportunity costs of environmental conservation in the Feijão River watershed (São Carlos-SP, Brazil). Braz J Biol 76(1):28-35

Mcinnes R, Smith G, Greaves J, Watson D, Wood N, Everard M (2016) Multicriteria decision analysis for the evaluation of water quality improvement and ecosystem service provision. Water Environ J 30(3-4):298-309. https://doi.org/10.1111/wej.12195

Mendonça F, Danni-Oliveira IM (2007) Climatologia: noções básicas e climas do Brasil. São Paulo: Oficina de textos, p 206 (in Portuguese)

Milani EJ, Faccini UF, Scherer CM, Araújo LM, Cupertino JÁ (1998) Sequences and stratigraphtc hierarchy of the Paraná basin (Ordovician to Cretaceous), southern Brazil. Bol IG-USP Sér Cient 29:125-173

Millennium Ecosystem Assessment (2005) Ecosystems and human well-being: synthesis. Island Press, Washington. http://www. millenniumassessment.org/documents/document.356.aspx.pdf. Accessed 5 Sept 2017

Montes LMV, Ruiz AM (2008) Environmental indicators to evaluate spatial and water planning in the coast of Granada (Spain). Land Use Policy 25(1):95-105

Morgan RPC (2005) Soil erosion and conservation, 3rd edn. Wiley, Oxford, $\mathrm{p} 304$

Morgan RPC, Quinton JN, Smith RE et al (1998) The European soil erosion model (EUROSEM): documentation and user guide. Version 3.6. Silsoe College: Bedford, p 124. http://eprints.lancs.ac. uk/13189/1/user_v2.pdf. Accessed 5 Jan 2017

Neitsch SL, Arnold JG, Kiniry JR, Srinivasan R, Williams JR (2010) Soil and water Assessment Input/Output File Documentation. Version 2009. Grassland, Soil and Water Research LaboratoryAgricultural Research Service, Blackland Research Center - Texas AgriLife Research. 604 p. (Texas Water Resources Technical Report, 365)

Nishiyama, L. (1991) Mapeamento geotécnico preliminar da quadrícula de São Carlos-SP. 228 f. M.S. thesis. Programa de PósGraduação em Geotecnia. Escola de Engenharia de São Carlos. Universidade de São Paulo (in Portuguese)
Nogami JS, Villibor DF (1979) Soil characterization of mapping units for highway purposes in a tropical area. Bull Eng Geol Environ 19:196-199

Paraguassu AB (1972) Experimental silicification of sandstone. Geol Soc Am Bull 83(9):2853-2858

Pejon OJ (1992) Mapeamento geotécnico da folha de Piracicaba-SP (escala 1:100.000): estudo de aspectos metodológicos, de caracterização e de apresentação dos atributos. 224 f. Ph.D. thesis. Programa de Pós-Graduação em Geotecnia. Escola de Engenharia de São Carlos. Departamento de Engenharia Civil. Universidade de São Paulo, São Carlos (in Portuguese)

Perrota MM, Salvador ED, Lopes RC, D'Agostinho LZ, Peruffo N, Gomes SD, Sachs LLB, Meira VT, Garcia MGM, Lacerda Filho JV (2005) Mapa Geológico do Estado de São Paulo, escala 1:750.000. Programa Geologia do Brasil - PGB, CPRM, São Paulo

Pimentel D, Harvey C, Resodudarmo P, Sinclair K, Kurtz D, Mcnair M, Crist S, Spritz L, Fitton L, Saffouri R, Blair R (1995) Environmental and economic costs of soil erosion and conservation benefits. Science 267:117-123. https://doi.org/10.1126/scien ce.267.5201.1117

Rapport DJ, Maffi L (2010) Eco-cultural health, global health, and sustainability. Ecol Res 26(6):1039-1049

Ravenga C (2005) Developing indicators of ecosystem condition using geographic information systems and remote sensing. Reg Environ Change 5(4):205-214. https://doi.org/10.1007/s10113-004-0085-8

Renard KG, Foster GA, Weesies GA, Mccool DK, Yoder DC (1997) Predicting soil erosion by water: a guide to conservation planning with the revised universal soil loss equation (RUSLE). Washington USDA, ARS, p 2-18, Agricul.Handbook 703. Agricultural Research Service. https://www.ars.usda.gov/ARSUserFiles/64080 530/rusle/ah_703.pdf. Accessed 17 Jan 2017

Reusser L, Bierman P, Rood D (2015) Quantifying human impacts on rates of erosion and sediment transport at a landscape scale. Geology 43:171-174. https://doi.org/10.1130/G36272.1

Soares JJ, Silva DW, Lima MIS (2003) Current state and projection of the probable original vegetation of the São Carlos region of São Paulo State, Brazil. Braz J Biol 63(3):527-536

Strahler AN (1952) Hypsometric (area-altitude) analysis of erosional topography. Geol Soc Am Bull 63(11):1117-1142

Tolentino M (2007) Estudo crítico sobre o clima da região de São Carlos. São Carlos: EdUFscar, p 76 (in Portuguese)

Trimble SW, Mendel AC (1995) The cow as a geomorphic agent A critical review. Geomorphology 13:233-253

Tundisi JG, Matsumura-Tundisi TM (2010) Impactos potenciais das alterações do Código Florestal nos recursos hídricos. Biota Neotrop 10(4):67-76 (in Portuguese)

United Nations World Water Assessment Programme (WWAP) (2015) The United Nations World Water Development Report 2015: water for a sustainable world. UNESCO, Paris

Uri ND, Lewis JA (1998) The dynamics of soil erosion in US agriculture. Sci Total Environ 218:45-58. https://doi.org/10.1016/S0048 -9697(98)00198-3

Valentin C, Poesen J, Li Y (2005) Gully erosion: impacts, factors and control. CATENA 63(2-3):132-153. https://doi.org/10.1016/j. catena.2005.06.001

Vente J, Poesen J, Verstraeten G, Govers G, Vanmaercke M, Rompaey AV, Arabkhedri M, Boix-Fayos C (2013) Predicting soil erosion and sediment yield at regional scales: Where do we stand? Earth Sci Rev 127:16-29. https://doi.org/10.1016/j.earsc irev.2013.08.014

Vitousek PM, Mooney HA, Lubchenco J, Melillo JM (1997) Human domination of earth's ecosystems. Science 277(5325):494-499. https://doi.org/10.1126/science.277.5325.494

Vrieling A, Hoedjes JCB, Van Der Velde M (2014) Towards large-scale monitoring of soil erosion in Africa: accounting for the dynamics 
of rainfall erosivity. Global Planet Change 115:33-43. https://doi. org/10.1016/j.gloplacha.2014.01.009

Wischmeier WH, Smith D (1978) Predinting rainfail erosion loses: a guide to conservation planning, Agriculture handbook. USDA, Washington, vol 537, p 52

Zhou J, Fu B, Gao G, Lü Y, Liu Y, Lü N, Wang S (2016) Effects of precipitation and restoration vegetation on soil erosion in a semi-arid environment in the Loess Plateau, China. CATENA 137:1-11. https://doi.org/10.1016/j.catena.2015.08.015

Zuquette LV (1981) Mapeamento geotécnico preliminar na região de São Carlos. 1981. 86 f. M.S. Escola de Engenharia de São Carlos. Departamento de Geotecnia. Universidade de São Paulo, São Carlos (in Portuguese) 